Ionian Islands, discovered near Santi Quaranta; Crepis rutilans, formerly only known from Corfu, found between Santi Quaranta and Valona; Cicer Montbretii, recorded only from Thrace; Geum heterocarpum and Cynoglossum pustulatum, both new to the Balkan Peninsula, the latter previously known only in southern Spain.

\section{Recent Additions to British Mammals}

THe recent discovery of a specimen of the squirreltailed or edible dormouse (Glis glis) in Shropshire, near Ludlow (Field, Jan. 4) is an interesting example of an alien mammal that has colonized parts of the British countryside. Although it is a controversial point with naturalists as to whether or not established aliens and feral escapes in the countryside should be admitted to the faunal list, some recorders do accept them when they are permanently established in the wild. Some fifty years ago, the late Lord Rothschild released specimens of the squirrel-tailed dormouse, a native of south Europe, near Tring, since when it has established itself in parts of Hertfordshire and Buckinghamshire and is increasing; but the Shropshire record is apparently farther north. There are small Japanese deer established in some woods in the Home counties and Lakeland, where they are often confused with roe deer, which also exist there, while an interesting example of feral animals establishing themselves are the herds of 'wild' goats that inhabit some of the mountains of Wales, as on Rhinog Fawr, near Llanbedr, where some of the old billies have huge horns ; and also in Scotland, where at least thirteen wild herds were counted a few years ago at places like Ben Lomond, at Dochfour near Inverness, on the Black Isle cliffs near Cromarty, in western Ross, Mull, Islay, Harris, Tiree, Rum, Arran and Eig. There was once a herd of feral goats on Ailsa Craig, but they were shot down because they interfered with the tame goats kept by the lighthouse keepers.

\section{British Woodlands}

Prof. A. G. Tansley discusses natural and seminatural British woodlands in a paper published in Forestry $(14,1 ; 1940)$. The native British woodlands have been so largely destroyed, and existing woods are now so extensively the results of planting and replanting, says Prof. Tansley, that foresters are naturally inclined to think of them all either as plantations, or as derelict and worthless wood and scrub, of value only as possible sites for new plantations. Some foresters will think that the accusation is correct; for many quite lose sight of the value and importance of a study of the historical part of a forest region or area which may have been once afforested. Prof. Tansley traces the progress of forest destruction in Britain from Neolithic times downwards to the present day. The island climate and the fact that Britain could always obtain all she required by imports removed from us the disabilities following severe deforestation in other parts of the world.
Briefly, Prof. Tansley's thesis is that for any given type of soil the old type of forest peculiar to the soil and locality will reappear, given a chance to do so. $\mathrm{He}$ believes that the old forest of, say, the south of England still persists in the many examples of coppice with standards, where oak is so commonly one of the chief species among the standards; and that with the exclusion of man and his flocks, and the rabbits and hares in excessive numbers, Nature would restore in time the same type of forest as originally existed over so large a part of the country. This claim can be substantiated by careful observation, not only in Great Britain but also in several tropical countries.

\section{Supply and Price of Bread}

AN important statement upon the supply and price of bread was made by the Minister of Food in the House of Lords on December 19 ; it was supplemented by the chairman of the Medical Research Council. Lord Woolton said that, although we are already spending $£ 35,000,000$ in subsidizing flour generally, an extra $£ 750,000$ is to be spent in three months (as from December 1, 1940) to keep the cost of all bread at $8 d$. or less for the $4 \mathrm{lb}$. loaf. He had further decided to adopt an 85 per cent extraction as a basis for wholemeal flour, which would be supplied at the same price as what was called "national straight run" white flour (70 per cent extraction). Synthetic vitamin $B_{1}$ will be added to the white flour, but supplies will probably not be available in any quantity until May. Lord Woolton is loth to force wholemeal bread upon the public for several reasons, one very important one being the failure of high-extraction flour to keep as well as white flour. But he has been impressed by the unaninimity of scientific opinion on the nutritive value of wholemeal bread, and therefore in the printed literature of the Ministry of Food he will continue to advocate its virtues.

Lord Balfour of Burleigh said that the Medical Research Council recommends that bread should be made of an extraction of the wheat grain of not less than $80-85$ per cent, and that a small percentage of calcium salt should be added to the flour. Although wholemeal flour contains more calcium than white flour, it is more essential to add calcium to the former than to the latter-an apparent paradox which both he and Lord Woolton seem to find difficult to understand. The reason is that wholemeal flour contains more phytic acid than white flour, and this acid prevents the absorption of calcium from the intestine. Lord Balfour continued that there is evidence that calcium deficiency has long been a defect of nutrition among people in Great Britain. On one point only did he disagree with Lord Woolton : he (Lord Balfour) was told that high-extraction flour, properly made, would keep suitably. In reply, Lord Woolton said that he intended to continue in ignorance of what a vitamin is, to rely upon the men of science who give him their support, and to advise the public of the results of this scientific research. 